\title{
MEAN REVERSION: AN INVESTIGATION FROM KARACHI STOCK EXCHANGE SECTORS
}

\author{
Jolita VVEINHARDT ${ }^{\mathrm{a}}$, Dalia STREIMIKIENE ${ }^{\mathrm{a}}$, Ahmed Raheem RIZWAN $^{\mathrm{b}}$, \\ Ahmad NAWAZc ${ }^{c}$ Aniqe REHMAN ${ }^{\mathrm{d}}$ \\ ${ }^{a}$ Institute of Sport Science and Innovations, Lithuanian Sports University, \\ Sporto g. 6, LT-44221 Kaunas, Lithuania \\ ${ }^{b}$ Department of Business Administration \& Commerce, Indus University, \\ Block-17, Gulshan, Karachi-75500, Pakistan \\ ${ }^{c}$ Department of Business Administration, Iqra University, Defence View, \\ Shaheed-e-Millat Road (Ext.), Karachi-75500, Pakistan \\ ${ }^{d}$ Department of Business Administration, Greenwich University, DK-10, \\ Street 38, Darakshan, DHA Phase VI, Karachi-75500, Pakistan
}

Received 24 September 2015; accepted 13 March 2016

\begin{abstract}
This article analyses the sectors of Karachi stock exchange in order to determine if there is any presence of mean reversion phenomenon in the stock market sectors and also an attempt to determine the pace of mean reversion. To conduct this research, secondary data is collected from the State Bank Bulletin. The frequency of the data is monthly. The variables include the individual; the data was obtained from 24 sectors returns over the period of 17 years from January 1992 to June 2008. The GARCH $(1,1)$ model was used to find the outcomes and the effects. In the two sectors out of 24 sectors, the GARCH and ARCH effects were significant, namely, in the Jute and Banks \& Investment Companies. We studied the mean reverting process in the KSE sectors over a specific time period. Since, the mean reversion varies over different time periods. Therefore, it would be a good area for future research to study the reasons, why the market reacts differently over different time periods and to determine the reasons for such variations. The paper contributes to Stock Prices returns and investment opportunities by studying the Mean Reversion Phenomenon.
\end{abstract}

Keywords: GARCH effects, ARCH effects, mean reversion, stock returns, exchange sectors.

JEL Classification: C32, G12, G15.

\section{Introduction}

Warren Buffett, the world's most successful investor said that stock prices forever fluctuate between unjustifiable optimism and unjustifiable pessimism. What Buffett meant to say was that the market may be overpriced at one point, fairly priced at another and yet under

Corresponding author Dalia Strimikiene

E-mail:dalia@mail.lei.lt 
priced at another. An explanation for Buffett's analogy may be explained by the fact that speculators in the market cause major fluctuations, while the investor brings rationality to the markets. For example, it is a known fact that when there is good news regarding a company listed in the stock market, the price will increase for the mentioned company. The speculator in the hope that the market will rise even further starts to place massive byorders in the markets leading to higher prices. The investor who is aware of the underline value of the stock realizes that he can make a nice profit by selling his stock at these inflated prices and he starts to place sell orders in the market (Campbell, Viceira 2005). This leads to lower prices. This in fact is one of the major reasons, which describe the phenomenon of "Mean reversion" (Kim et al. 1991). According to Andreou and Werker (2015) the rankbased tests often, though not always, have superior power properties over the classical tests, even if they are conservative. Simulations show that their asymptotic approximations work well for a large number of AR-GARCH models and parameter values. Bentes (2015) examined the accuracy of implied volatility and GARCH forecasted volatility to predict the behavior of realized volatility. The results clearly show that GARCH forecasted volatility outperforms implied volatility to produce out-of-sample forecasts based on a subsample of the total sampling period for the four stock markets analyzed.

Purpose of this research. Mean reversion refers to the concept that once prices move away from the mean or intrinsic value; over time they will eventually revert back to these mean value. The purpose of this study is to analyze the sectors of Karachi Stock Exchange in order to determine if there is any presence of mean reversion phenomenon in the stock market sectors. If this study leads then to believe that there is reversion to mean phenomenon in the sectors then we will also attempt to determine the pace at which mean reversion takes place.

Mean reversion in developed and developing markets. Like the alchemists were searching for the philosopher's stone in the middle ages, finance experts, today, are busy searching to determine predictability in stock prices. However as the stock prices depend on a number of different fundamentals, some experts believe that prices are completely unpredictable (Pavlenko 2008). This is outlined by the efficient market hypothesis, which was very popular in the previous decades. Since the empirical data available to support the efficient market hypothesis was not persuasive enough, many new theories came up which were against the random walk theory. One of the most empirically supported theories was the mean reversion theory. The theory states that market prices deviate from their fundamental or intrinsic value, but then revert back to the fundamental value (Summers 1996; Mackevicius et al. 2012; Girdzijauskas et al. 2008). Mean reversion is either present in stock markets at one time and may not be present at another. Even if it is present in two different markets, it's highly likely that the rate of mean reversion, or how fast or slowly the prices revert back to the mean, is different for different national markets (Malliaropulos, Priestley 1999; Teresiene et al. 2008). In the US, which is a developed country, mean reversion was found to exist in the stock market, especially after World War II. It is important to point out that there is a major difference between developed country stock markets and developing nation markets and as a result there are bound to differences in the results regarding mean reversion in both types of markets (Fama 1960). 
Reasons for mean reversion and how it removes market inefficiency. One well-known fact is that market traders pay a lot of attention to recent returns and do not pay much attention to the long-term dividend paying power of public companies. This focus on recent returns leads speculators to overreact when a company performs well and its price increases, speculators believe that because the price has gone up, they hope and believe that the price will keep going up in the future and the company will keep providing better and higher returns (Kasa 1992). As they buy into such stocks the price goes up even higher as a result and the stocks become considerably overvalued. Investors, who are known to bring rationality to the markets, sell their stocks on seeing them selling at such high prices which in turn brings the prices down to their mean or intrinsic value. Hence mean reversion takes place. As a result of these major fluctuations in prices from their high levels and back down to intrinsic value causes much misallocation of funds (De Bondt, Thaler 1985). The firms that were selling for very high multiples due to good performance in latest periods and also due to the hope that prices will keep going higher, is allocated a large part of the market capital while the firms which have not performed too well but have the potential to do well and hence provide better potential upside for investors is allocated, comparatively, little market capital. This greater allocation of capital to firms with lower potential upside, and possibly greater downside price risk, and the comparatively lower allocation of capital to firms with higher potential upside are known as market inefficiency (De Bondt, Thaler 1987).

Some evidence in support of market inefficiency. In this research researchers came across a number of factors, which point to the fact that market prices may deviate from their mean or intrinsic value. The first point is that inefficiency caused by speculators (Kasa 1992). The main difference between a speculator and investor is that investors base their investment decisions on sound fundamental principles while the speculator basis his buy sell decisions on hope. When a speculator sees the price of a company go up considerably, hence making it more expensive, the speculator decides to buy with the hope that the price will keep going higher. This buying of expensive stocks leads to even higher prices hence making the stock even more overvalued (De Bondt, Thaler 1987). The investor on seeing such an opportunity to sell his stock at prices much higher than their intrinsic worth sells the stock in the market, which again brings the stock back down to its intrinsic worth. What we are trying to point out here is that the speculator first made the stock overvalued or in other words created market inefficiency (De Bondt, Thaler 1985).

Relative mean reversion. Due to lack of powerful statistical tools and a small sample size, there is lack of substantial evidence in favor of mean reversion. In order to improve the estimation methods relative mean reversion is used where returns are compared against a specific mean value or intrinsic value. Since fundamental value needs to be calculated using estimates we use the Gordon growth model or the dividend discount model in order to arrive at our intrinsic valuation. The Gordon growth model simply takes the next year's dividends and divides them by the required returns minus growth rate of dividends. The logic behind this model is that the value of the firm is the present value of the future cash flows that the firm will generate for its shareholders in the form of dividends (Gordon 1959, 1962). Aside from these valuation models there are other techniques for determining intrinsic value e.g. ratio analysis and all of these ratios are said to be mean reverting (Eas- 
ton et al. 2013). All of these methods can be used to determine mean values, which might deviate from the mean but will eventually return to the mean values again. The theory is that in case the market prices deviate from the mean value then an adjustment is needed in order to bring the market price back to the mean value or the mean value will change and adjust to the new market price. Campbell and Schiller $(1988,2001)$ found that it is usually market price that adjusts back to the mean value and not the other way around.

Pace of mean reversion \& economic uncertainty. The data supports the fact that mean reversion is highest during periods of high economic uncertainty. Periods of high economic uncertainty are periods such as the Great Depression, Cold War and World War II. As it is an empirically proven fact that mean reversion may occur in efficient markets due to the fact that prices are based on expected returns and when expected returns are mean reverting, prices in efficient markets are also mean reverting. Mean aversion may be caused in efficient markets when there is news or fear of an economic collapse or any other such impending doomsday scenario. In such a case the expected returns are more likely to avert from the mean, which is they are more likely to fall when such news comes into the market. However when expectations regarding the economy change, that is they come back to normal, the market is likely to recover from the previous collapse and come back to their long term values, in other words are mean reverting (Cecchetti et al. 1990). Studies show that this aversion from the mean and then the mean reversion happen rather quickly in periods of high economic uncertainty and comparatively is much lower during periods of high economic tranquility. Intervention by financial institutions and governments are more likely to play a greater role in this greater speed of mean reversion during such volatile times. Under the assumption of inefficient markets, noise traders or speculators as they are commonly known cause markets to deviate from the mean and then again cause the markets to revert back as well (Dennis, Strickland 2002). When there is news of impending doom, speculators who are not aware of any fundamental values, overreact and cause prices to fall substantially during this period and cause mean aversion. However when news comes to economic stability and prosperity these same people are more likely to return to the markets with their capital and invest in the markets again causing prices to rise quickly in a relatively short time period (Engle, $\mathrm{Ng} 1993$ ).

Research question. Is there reversion to mean phenomenon in KSE sectors and at what pace?

\section{Hypotheses:}

$\mathrm{H}_{1}$ : All sectors are subject to mean reversion.

$\mathrm{H}_{2}$ : All sectors have ARCH effects.

$\mathrm{H}_{3}$ : All sectors have GARCH effects.

Previous research. Cutler et al. (1991) in their study "speculative dynamics" put forward the view that excess returns (returns greater than market return) may be earned due to the speculative dynamics, which are brought about by the speculator who is not rational in the conventional sense. These people do not act in a rational way given all public information relevant to a stock. The data set used in their study points to regularities in asset returns. For instance the first is that asset returns are positively correlated at high frequencies, 
second that asset returns are negatively correlated at lower frequencies, third that asset prices revert to their fundamental values over time and finally asset returns are low when interest rates are high.

Pavlenko (2008) said randomness of prices was empirically proven as later on a number of non-random walk hypothesis emerged. One of the most empirically supported hypotheses is the mean reversion hypothesis. The concept behind this concept is that prices deviate from their mean values and then later on due to certain reasons these prices come back to their original mean values. What Pavlenko said was that mean reversion in developed and developing markets is a phenomenon, which happens for different reasons. In his study he talked only of developing countries where he said that the average age of companies and political connections were two important issues which either led to mean reversion or prevented it.

In the case of the average age of companies the fact was that the average age of companies was comparatively small and due to this reason these companies had still not developed competitive advantages which would help them hold on to their market share in case of new competition in the markets. This led to a situation where periods of high profitability were followed by very low performance periods as new firms entered the markets and took away the share of these companies after profitable periods. This led to mean reversion phenomenon. The other issues of political connections in these countries where a firm due to its political connections could simply out perform its competitors and continue to do so for long periods of time (Pavlenko 2008).

Cecchetti et al. (1990) talked about mean reversion and some reasons why mean reversion may take place. The reason that he gave was that when firms perform well and their prices go up in the stock market, these firms might want to expand their operations. Now in order to expand it is possible that the firm takes up leverage. If this happens then a chain reaction occurs which eventually leads to mean reversion. This chain reaction was that when the firm takes up more debt the firms liquidity position is weakened along with its balance sheet and as a result the rating agencies may decide to lower the credit rankings of the firm which in turn would make it more expensive for the firm to borrow money and hence lowering its profitability and bringing down the share price down with it.

Spierdijk et al. (2010) used annual data from year 1900-2008 in order to determine signs of mean reversion in international stock markets. Using the data from almost a 100 years and using seventeen developed countries helped analyze mean reversion in detail. The study shows that it takes 13.8 years in order to absorb half of a price shock. The study used a rolling window approach and large fluctuations were there in the speed of mean reversion over this time period. However the study points out that the highest speed of mean reversion was found during economic uncertain times such as the great depression and World War II.

Vlaar (2005) in his study argued that mean reversion makes investing in stocks much more attractive to investors, both institutional and individual investors. he said that by exploiting the mean reverting behavior of prices an investor could earn abnormal returns, otherwise known as excess returns, and benefit from the mean reversion phenomenon. This same concept made it more enticing for pension funds to invest in equity markets. his 
basic premise was that if stock returns are mean reverting, then lower returns will mostly be followed by higher returns so pension funds could simply wait for the stock market to come down so that they could buy the stocks at these lower levels only for the stock to return to their previous highs and even higher still.

Fama and French (1988a, 1988b), Poterba and Summers (1988) were the first to provide the concept of absolute mean reversion. Absolute mean reversion refers to the concept of mean reversion without a known specific mean value or otherwise known as negative autocorrelation in stock returns. They attributed $25-40 \%$ of variations in stock returns, in periods of 3 to 5 years to negative auto correlation. The investment horizon taken in these studies were between one and ten years and that resulted in proof in favor of absolute mean reversion. Portreba and Summers (1988) used specific properties of the random walk hypothesis in order to prove significant negative auto correlation or absolute mean reversion. In their studies both Fama and French (1988a), Potreba and Summers (1988) used yearly overlapping returns, from 1926 to 1985 , in order to increase the number of observations, which raises the issue dependency. This issue of dependency was solved by using the method of Hansen and Hodrick (1980). Richardson and Smith (1991) however criticized this approach and stated that the use of the small sample size bias results in evidence in favor of mean reversion over the long run however if they were to remove the small sample size bias the evidence in favor of mean reversion would vanish along with the small sample size.

Hillebrand (2003) discussed the issue of mean reversion and said that it was the phenomenon where higher returns are followed by lower returns and vice versa. He stated that the speed with which the markets revert to their means is different in different countries due to different reasons. Hillebrand said that all market participants will develop expectations regarding the speed of mean reversion and these expectations will determine their actions in the market. For example if the investor had a long position in the markets after very high returns and the investor expects these returns to disappear quickly then the investor will most probably sell his long position in order to realize the high returns, but incase the investor has a short position and expects the returns to disappear quickly then he will hold on to the investment position and possibly even add to it because he expects the market to go down quickly and that he may be able to cover his short and make a profit in the process.

Black (1976) talked about how decreasing the equity in a business could lead to higher risk and volatility which would lead to lower prices and thus mean reversion. What he said was that if a business reduces its equity capital it is more likely that the future cash flows will also go down hence taking down the actual value and price of the stock. On the other hand the way a lower equity capital structure affects prices is that the lower equity would lead to a higher debt to equity ratio which would mean that the firm now has more debt on its head and this would make the company financially weaker than before hence making it more risky as its stock would become more volatile. This effect is called the leverage effect. The leverage effect leads to mean reversion as more leverage makes the stock comparatively more risky and hence it becomes more volatile and investors demand a premium on it causing prices to fall causing mean reversion. 
Balvers et al. (2000) talked about momentum and contrarian investment strategies. They said that contrarian strategies are those where an increase in stock market returns is followed by investors selling their stocks as they are most likely overvalued and a fall in prices is followed by buy orders as the stock is probably undervalued and a better buy. Momentum strategies are those in which the investor purchases after a stock market increase with the hopes that the market will continue to rise and when the market falls the investor sells his stock with the belief that market will continue its momentum and continue to fall. Balvers et al. (2000) said that there is no contradiction between the gain potential of both the different investing strategies as contrarian strategies work for a sorting period ranging from 3 to 5 years periods while momentum strategies work for a sorting period of 1 to 12 months.

Jegadeesh (1991) stated that mean reversion phenomenon, based on his studies was mostly concentrated in January. This phenomenon is also known as the January effect. According to his concept stock prices of small cap stock falls during December and then returns to mean prices by January in the New Year. According to the study mean reversion is present in January using both equally weighted and value weighted indices. The reason behind the January effect is that during December most institutional investors and individual investors sell of their small cap stock so that they may lock in capital losses for tax purposes. However after the New Year starts these same investors buy back the stocks they had sold earlier causing prices to revert to the mean.

Nam et al. (2003) said that there is a lot of evidence that supports the idea that stock returns do not follow random walk. Although much of the evidence supports the phenomenon of mean reversion, however due to the different interpretations of researchers two different competing hypothesis have emerged. The first one is the time varying rational expectations and the second is the stock market over reaction bias. Under the first hypothesis, mean reversion is a phenomenon, which is caused by the revision of expectations of returns that are made as a result of changes in price volatility. Fama and French (1988b) argue that the deviation of stock prices from its mean causes an increase in volatility which makes the stock more risky leading to investors demanding a higher premium for the specific security. This increase in the risk premium also causes the price to fall hence causing mean reversion.

The second hypothesis is the cause of investors over reacting to market news causing prices to deviate from their fundamentals. In case good news hits the market the investors will be overly optimistic and buy the security till it deviates from its mean and the same goes for bad news where the bad news causes investors to oversell the security, causing prices to fall. However the studies have shown that poor performers in the past have a higher likely hood of performing better in the future while the good performers are more likely to underperform.

Bailey and Gilbert (2007) concluded that many investors have put in great effort in order to be able to determine future price movements in the market by studying previous market data or market prices. However this desire to achieve abnormal profits has been challenged by studies and theories, which suggest that markets are efficient and that a free lunch is not possible. However studies carried out by Cubbin et al. (2006) show that markets are not always efficient and that market inefficiency might arise from time to time. 
One question that remains is that if this phenomenon of mean reversion is that popular then how is this phenomenon still persistent in markets as logic suggests that the rational investor would move into the market whenever this anomaly arises and this would lead back to market efficiency.

Lo and MacKinlay (1988) have tried to distinguish between long term and short term mean reversion and tried to determine if markets revert to their means in the short term or the long run. Lo and Mackinlay did a study concluding that there was evidence of positively correlated returns which did not follow random walk. Their paper concluded that there was no evidence of long term mean reversion. The concept applies that even if the past has shown evidence of long term mean reversion, there is no guarantee that it will continue to persist in the future as well. However there have been several studies that clearly point to the existence of short term mean reversion. An example is the January effect where stock returns fall in December and then revert back to the mean in the next year in January. Wang et al. (2015) used a fusion model to investigate the coexistence of three distinctive dynamic features of Chinese stock and stock index futures markets: permanent volatility, transitory volatility and jumps. These three features are included in the component-GARCH-jump model proposed in the research. The empirical results show that permanent volatility has smooth movement and that the transitory volatilities strongly resemble each other.

Pastor and Stambaugh (2012) suggest that stocks are less volatile over long run as a result of mean reversion, studies however show a completely different picture. Studies show that stocks are more volatile over long term as a result of the uncertainties associated with them in the long run. The studies show that although long run variance is negatively affected by mean reversion however other factors more than offset this effect. The authors concluded that although long run mean variance is reduced substantially by mean reversion however other factors related to the stocks risk and return factors more than offset this effect causing long run mean variance to be much higher than short run variance. One of these factors, which contribute to long run variance, is the unpredictability of future returns. Since future returns are uncertain in stocks there for this factor causes the long-term variance to be higher for stocks as compared to fixed income securities or debt securities. The studies show that stocks over the long run are more volatile as compared to short run and therefore making them not as appealing to long-term investors than what conventional wisdom would suggest. However this in no way proves investors with a long-term perspective should invest any less in stocks than an investor with a short investment horizon.

\section{Research methodology}

Orabi and Alqurran (2015) studied that the Middle East financial markets have experienced several unexpected volatility shifts during the last two decades had recorded a serious impact on these markets and caused a financial turmoil that has elevated the uncertainties in the region. Research results provided significant empirical evidence for positive risk-return relationship in the stock exchange. Iqbal and Riaz (2015) inspected the pragmatic association among daily traded volume of stocks, volatility as well as daily stock returns by taking one market index that is FTSE 100 and five individual stocks trading on FTSE 100. The five 
stocks which are under examination are traded on FTSE 100 belongs to different sectors. The stocks are selected randomly by keeping in mind the fact that one from each sector. Kitatia et al. (2015) investigated the effect of the selected macro-economic variables on share prices of the companies listed on the Nairobi Securities Exchange, simple and multi-variate regressions analysis was used. For all of the quoted companies it was desirable to find if the stock prices fluctuations are predominantly due to the selected macro-economic variables. The study found that interest rate had a predominant effect on stock market price indices as compared to the other macro-economic variables. Interest rate, exchange rate for both the Euro and US Dollar had a negative effect on stock market indices for companies quoted on the Nairobi Securities Exchange. When the Kenya shilling depreciates the stock market indices gain in points. The inflation rate had a negative effect on stock market performance indicating that higher levels of inflation rate result in lower stock market indices in Kenya. Boussaidi and Kouki (2015) research results indicate that although stock prices diverge away from their fundamental value proxied by dividends or earnings, there is an error correction mechanism, which adjusts stock prices to revert back to their fundamental value. Evidence also shows that mean reversion supports the predictability of stock returns by the dividend to price and the price to earnings ratios. According to Posedel (2005), empirical studies basedon the log return time series data of some US stocks showed the following observations, the so-called stylized facts of financial data: serial dependence are present in the data; volatility changes over time; distribution of the data is heavy-tailed, asymmetric and therefore not Gaussian. Posedel (2005) maintains that these observations clearly show that a random walk with Gaussian increments is not a very realistic model for financial data. It took some time before Engle found a discrete model that described very well the previously mentioned stylized facts of financial data, but it was also relatively simple and stationary so the inference was possible. Engle called his model autoregressive conditionally heteroskedastic- ARCH, because the conditional variance (squared volatility) is not constant over time and shows autoregressive structure. Furthermore ARCH models still are attracting an interest of the researchers (Kononovicius, Ruseckas 2015). Some years later, Bollerslev generalized the model by introducing generalized autoregressive conditionally heteroskedastic - GARCH model (Posedel 2005). The properties of GARCH models are not easy to determine. Integer-valued generalized autoregressive conditional heteroscedasticity models have played an important role in time series analysis of count data (Zhu et al. 2015). Kristjanpoller and Minutolo (2015) note that one of the most used methods to forecast price volatility is the generalized autoregressive conditional heteroskedasticity (GARCH) model, though some discussions appear on different dimensions (Kristjanpoller, Minutolo 2015; Han 2015; Paolella 2015; Liu, Luger 2015; etc.). According to Kinoshita (2015) with the GARCH effects, a simple approach to estimate conditional higher moments is given. GARCH models include most of the stylized facts of financial time series and they have been largely used to analyse discrete financial time series (Marin et al. 2015).

In order to determine if mean reversion exists in KSE sectors and if so then at what pace, we consider the KSE sectors. The data, which has been used in this report, uses monthly return observations for the 24 sectors starting from January 1992 to June 2008. The data for our research was acquired through the State Bank Statistical bulletin. In order to run the data and attain our results I used MS Excel and the GARCH estimation tool in Excel. 
Data and Variables. To conduct this research, secondary data is collected from the State Bank Bulletin. The frequency of the data is monthly. Variables include the individual sectors.

Sample. The time that will be focused for the sample is January 1992 to June 2008.

Model. GARCH will be used in order to determine whether there is fast or slow mean reversion.

Econometric Analysis. Bollerslev (1986) independently developed the Generalized Autoregressive Conditional Heteroskedasticty model. This model contains two distributed lags. The first lag is used to capture high frequency effects on lag-squared residuals and second to capture the long-term effects of the lagged values of variance.

$$
\operatorname{var}\left(\varepsilon_{t} \mid \psi_{t-1}\right)=\text { conditiond variance, }
$$

where, $\psi_{t-1}$ is the information set available at first lag of time.

For GARCH $(p, q)$ :

$$
\sigma_{t}^{2}=\omega+\sum_{i=1}^{q} \alpha_{i} \varepsilon_{t-i}^{2}+\sum_{j=1}^{p} \beta_{i} \sigma_{t-j}^{2},
$$

where: $\omega, \alpha, \beta=$ Coefficients; $\varepsilon_{t-1}^{2}=1^{\text {st }}$ lag of Square returns (ARCH (1)); $\sigma_{t-1}^{2}=$ Trailing variance (GARCH (1)).

The GARCH $(1,1)$ model uses the expected variance as a mix of long run variance and the last period expected variance, which is also adjusted for the last periods observed shock. Estimates are used in the GARCH model for the trailing conditional variance, the sum of coefficients on the lagged squared returns and data on returns of financial returns, which are all close to one. This means that the conditional variance will be persistent in the face of shocks yet however it is still mean reverting as the conditional variance is still less than one. This means that although volatility might take a long time before prices revert back to mean however it does happen and mean reversion does take place. This means that there is the possibility to make projections in the future. The literature on SV models is vast and rapidly growing, and excellent surveys are already available on the subject, e.g., Ghysels et al. (1996), Shephard (1996). Consequently, we focus on providing an overview of the main approaches with particular emphasis on the generation of volatility forecasts within each type of model specification and inferential technique. Long run average variance is $\sqrt{\omega / 1-\alpha-\beta}$ which is only applicable when $\alpha+\beta<1$ and $\alpha>0, \beta>0$, and $\omega>0$.

\section{Results and analysis}

GARCH $(1,1)$ is applied via ML-BFGS which is an analytical gradient developed for Microsoft Excel as an add-in. All three parameters $\omega, \alpha, \beta$ of GARCH $(1,1)$ model are significant for all sectors as $p<0.1$ which means that long run variance, $1^{\text {st }}$ lag square returns and trailing variance are significantly explaining the conditional variance. Further the sum of GARCH coefficients i.e. $\omega, \alpha, \beta$.

In Table 1 GARCH coefficients are provided. If it approaches 1 , i.e. $\alpha+\beta \rightarrow 1$ 
Table 1. GARCH coefficients

\begin{tabular}{lccccc}
\hline \multicolumn{1}{c}{ Sectors } & $\Omega$ & A & B & $\begin{array}{c}\text { Sum of GARCH } \\
\text { Coefficients }\end{array}$ & LRAV \\
\hline $\begin{array}{l}\text { Banks and Investment } \\
\text { Companies }\end{array}$ & 0.000139 & 0.490527 & 0.140946 & 0.631612062 & 0.019412 \\
\hline Jute & 0.000399 & 0.275655 & 0.446583 & 0.722638042 & 0.037921 \\
\hline
\end{tabular}

Since $\alpha+\beta<$ land sum of GARCH coefficients is also less than 1 , therefore the essential conditions for the model are fulfilled. Long run average variances (LRAV) for the sectors' returns are also calculated (using $\sqrt{\omega /(1-\alpha-\beta)}$ ) as described by Engle (2001), which has got the highest value of $3.79 \%$ for Jute, which has the highest weight for trailing variance of 0.4465 followed by $1.94 \%$ for Banks and Investment Companies with 0.1409 weights for trailing variance.

Since the sum of coefficients for all market returns' is less than 1, which is required to have a mean reverting variance process. As the sum of coefficients gets closer to 1, the process of mean reversion gets slower as sighted in Engle (2001). Here, Banks and Investment Companies and Jute, both have got the fast mean reversion process as the sum of coefficients is 0.63 and 0.72 respectively, which is far from 1 .

The output of GARCH $(1,1)$ for individual sectors is given in Table 2.

Table 2. GARCH $(1,1)$ output for individual sectors

\begin{tabular}{|c|c|c|c|c|c|c|c|c|}
\hline & \multicolumn{4}{|c|}{$\begin{array}{l}\text { GARCH }(1,1) \text { estimation of cotton } \\
\text { and other textiles }\end{array}$} & \multicolumn{4}{|c|}{$\begin{array}{l}\text { GARCH }(1,1) \text { estimation } \\
\text { of textile spinning }\end{array}$} \\
\hline Method & \multicolumn{4}{|c|}{ ML - BFGS with analytical gradient } & \multicolumn{4}{|c|}{ ML - BFGS with analytical gradient } \\
\hline $\begin{array}{l}\text { Included } \\
\text { observations }\end{array}$ & \multicolumn{4}{|c|}{197} & \multicolumn{4}{|c|}{197} \\
\hline \multirow[t]{2}{*}{$\begin{array}{l}\text { Convergence } \\
\text { achieved }\end{array}$} & \multicolumn{4}{|c|}{ after 96 iterations } & \multicolumn{4}{|c|}{ after 54 iterations } \\
\hline & Coefficient & Std. Error & $z$-Statistic & Prob. & Coefficient & Std. Error & $z$-Statistic & Prob. \\
\hline Omega & $2.52 \mathrm{E}-06$ & $2.01 \mathrm{E}-06$ & 1.251225 & 0.210852 & $3.38 \mathrm{E}-05$ & 0.000192 & 0.176162 & 0.860167 \\
\hline alpha_1 & 0.902678 & 0.071563 & 12.61369 & 0 & 0.05147 & 5.37632 & 0.009574 & 0.992362 \\
\hline beta_1 & 0.038349 & 0.024062 & 1.593743 & 0.110994 & 0.003109 & 0.021635 & 0.143687 & 0.885748 \\
\hline $\begin{array}{l}\text { Log } \\
\text { Likelihooc }\end{array}$ & 733.8934 & & & & 715.3947 & & & \\
\hline Jarque Bera & 2997.83 & & Prob & 0 & 1121.552 & & Prob & 0 \\
\hline \multirow[t]{2}{*}{ Ljung-Box } & 0.037367 & & Prob & 0.846719 & 0.076613 & & Prob & 0.781941 \\
\hline & \multicolumn{4}{|c|}{ GARCH $(1,1)$ estimation of textile weaving } & \multicolumn{4}{|c|}{ GARCH $(1,1)$ estimation of other textiles } \\
\hline Method & \multicolumn{4}{|c|}{ ML - BFGS with analytical gradient } & \multicolumn{4}{|c|}{ ML - BFGS with analytical gradient } \\
\hline $\begin{array}{l}\text { Included } \\
\text { observations }\end{array}$ & \multicolumn{4}{|c|}{197} & \multicolumn{4}{|c|}{197} \\
\hline \multirow[t]{2}{*}{$\begin{array}{l}\text { Convergence } \\
\text { achieved }\end{array}$} & \multicolumn{4}{|c|}{ after 46 iterations } & \multicolumn{4}{|c|}{ after 101 iterations } \\
\hline & Coefficient & Std. Error & $z$-Statistic & Prob. & Coefficient & Std. Error & $z$-Statistic & Prob. \\
\hline Omega & 0.000214 & 0.000661 & 0.32364 & 0.746211 & $2.17 \mathrm{E}-07$ & $1.11 \mathrm{E}-07$ & 1.959161 & 0.050094 \\
\hline alpha_1 & 0.070948 & 2.839018 & 0.02499 & 0.980063 & 0.738966 & 0.021244 & 34.78463 & 0 \\
\hline
\end{tabular}


Continue of Table 2

\begin{tabular}{|c|c|c|c|c|c|c|c|c|}
\hline beta_1 & 0.002172 & 0.045601 & 0.047629 & 0.962012 & 1.007548 & 0.168767 & 5.970061 & 2.37E-09 \\
\hline $\begin{array}{l}\text { Log } \\
\text { Likelihooc }\end{array}$ & \multicolumn{4}{|l|}{556.0431} & \multicolumn{4}{|l|}{680.214} \\
\hline Jarque Bera & 3278.324 & & Prob & 0 & 47475.43 & & Prob & 0 \\
\hline \multirow[t]{2}{*}{ Ljung-Box } & 0.378702 & & Prob & 0.538299 & 65535 & & Prob & 65535 \\
\hline & \multicolumn{4}{|c|}{ GARCH $(1,1)$ estimation of chemical \& pharmaceutical } & \multicolumn{4}{|c|}{ GARCH $(1,1)$ estimation of engineering } \\
\hline Method & \multicolumn{4}{|c|}{ ML - BFGS with analytical gradient } & \multicolumn{4}{|c|}{ ML - BFGS with analytical gradient } \\
\hline $\begin{array}{l}\text { Included } \\
\text { observations }\end{array}$ & \multicolumn{4}{|c|}{197} & \multicolumn{4}{|c|}{197} \\
\hline \multirow[t]{2}{*}{$\begin{array}{l}\text { Convergence } \\
\text { achieved }\end{array}$} & \multicolumn{4}{|c|}{ after 36 iterations } & \multicolumn{4}{|c|}{ after 47 iterations } \\
\hline & Coefficient & Std. Error & $z$-Statistic & Prob. & Coefficient & Std. Error & $z$-Statistic & Prob. \\
\hline Omega & 0.001823 & 0.008965 & 0.203321 & 0.838884 & 0.00028 & 0.000651 & 0.429109 & 0.667844 \\
\hline alpha_1 & 0.039999 & 4.721547 & 0.008472 & 0.993241 & 0.057885 & 2.185709 & 0.026483 & 0.978872 \\
\hline beta_1 & 0.002385 & 0.016599 & 0.143672 & 0.88576 & 0.007708 & 0.038057 & 0.202537 & 0.839497 \\
\hline $\begin{array}{l}\text { Log } \\
\text { Likelihooc }\end{array}$ & 345.7588 & & & & 528.2813 & & & \\
\hline Jarque Bera & 282133.3 & & Prob & 0 & 3592.281 & & Prob & 0 \\
\hline \multirow[t]{2}{*}{ Ljung-Box } & 0.005905 & & Prob & 0.938746 & 0.201517 & & Prob & 0.653499 \\
\hline & \multicolumn{4}{|c|}{ GARCH $(1,1)$ estimation of auto an allied } & \multicolumn{4}{|c|}{ GARCH $(1,1)$ estimation of cables and electric goods } \\
\hline Method & \multicolumn{4}{|c|}{ ML - BFGS with analytical gradient } & \multicolumn{4}{|c|}{ ML - BFGS with analytical gradient } \\
\hline $\begin{array}{l}\text { Included } \\
\text { observations }\end{array}$ & \multicolumn{4}{|c|}{197} & \multicolumn{4}{|c|}{197} \\
\hline \multirow[t]{2}{*}{$\begin{array}{l}\text { Convergence } \\
\text { achieved }\end{array}$} & \multicolumn{4}{|c|}{ after 38 iterations } & \multicolumn{4}{|c|}{ after 46 iterations } \\
\hline & Coefficient & Std. Error & $z$-Statistic & Prob. & Coefficient & Std. Error & $z$-Statistic & Prob. \\
\hline Omega & 0.000184 & 0.001422 & 0.129261 & 0.897151 & 0.000258 & 0.002098 & 0.122846 & 0.902229 \\
\hline alpha_1 & 0.048964 & 7.34925 & 0.006662 & 0.994684 & 0.050719 & 7.726033 & 0.006565 & 0.994762 \\
\hline beta_1 & 0.003996 & 0.036077 & 0.110759 & 0.911808 & 0.002112 & 0.03772 & 0.056002 & 0.95534 \\
\hline $\begin{array}{l}\text { Log } \\
\text { Likelihooc }\end{array}$ & 545.7585 & & & & 539.507 & & & \\
\hline Jarque Bera & 1506.347 & & Prob & 0 & 4502.416 & & Prob & 0 \\
\hline \multirow[t]{2}{*}{ Ljung-Box } & 0.26986 & & Prob & 0.603426 & 0.143184 & & Prob & 0.705136 \\
\hline & \multicolumn{4}{|c|}{ GARCH $(1,1)$ estimation of sugar and allied } & \multicolumn{4}{|c|}{ GARCH $(1,1)$ estimation of paper and board } \\
\hline Method & \multicolumn{4}{|c|}{ ML - BFGS with analytical gradient } & ML & BFGS with & alytical gra & \\
\hline $\begin{array}{l}\text { Included } \\
\text { observations }\end{array}$ & & 19 & & & & & & \\
\hline $\begin{array}{l}\text { Convergence } \\
\text { achieved }\end{array}$ & & after 55 it & ations & & & after 53 & rations & \\
\hline & Coefficient & Std. Error & $z$-Statistic & Prob. & Coefficient & Std. Error & $z$-Statistic & Prob. \\
\hline Omega & $5.56 \mathrm{E}-05$ & $5.41 \mathrm{E}-05$ & 1.027546 & 0.304164 & $3.16 \mathrm{E}-05$ & 0.000929 & 0.034053 & 0.972835 \\
\hline alpha_1 & 0.124368 & 0.835789 & 0.148803 & 0.881709 & 0.051508 & 27.8516 & 0.001849 & 0.998524 \\
\hline beta_1 & 0.007021 & 0.030296 & 0.231732 & 0.816746 & $2.27 \mathrm{E}-05$ & 0.024573 & 0.000924 & 0.999263 \\
\hline $\begin{array}{l}\text { Log } \\
\text { Likelihooc }\end{array}$ & 662.8724 & & & & 719.0084 & & & \\
\hline Jarque Bera & 9126.302 & & Prob & 0 & 694.4911 & & Prob & 0 \\
\hline Ljung-Box & 0.027652 & & Prob & 0.86793 & 0.313417 & & Prob & 0.575591 \\
\hline
\end{tabular}


Continue of Table 2

\begin{tabular}{|c|c|c|c|c|c|c|c|c|}
\hline & \multicolumn{4}{|c|}{ GARCH $(1,1)$ estimation of cement } & \multicolumn{4}{|c|}{ GARCH $(1,1)$ estimation of fuel and energy } \\
\hline Method & \multicolumn{4}{|c|}{ ML - BFGS with analytical gradient } & \multicolumn{4}{|c|}{ ML - BFGS with analytical gradient } \\
\hline $\begin{array}{l}\text { Included } \\
\text { observations }\end{array}$ & \multicolumn{4}{|c|}{197} & \multicolumn{4}{|c|}{197} \\
\hline \multirow{2}{*}{$\begin{array}{l}\text { Convergence } \\
\text { achieved }\end{array}$} & \multicolumn{4}{|c|}{ after 51 iterations } & \multicolumn{4}{|c|}{ after 36 iterations } \\
\hline & Coefficient & Std. Error & $z$-Statistic & Prob. & Coefficient & Std. Error & $z$-Statistic & Prob. \\
\hline Omega & 0.000327 & $6.25 \mathrm{E}-05$ & 5.227629 & $1.72 \mathrm{E}-07$ & 0.002461 & 0.032495 & 0.075743 & 0.939624 \\
\hline alpha_1 & 0.059771 & 0.12582 & 0.475055 & 0.634748 & 0.042839 & 12.63686 & 0.00339 & 0.997295 \\
\hline beta_1 & 0.373142 & 0.073391 & 5.084321 & $3.69 \mathrm{E}-07$ & 0.000717 & 0.012033 & 0.059549 & 0.952515 \\
\hline $\begin{array}{l}\text { Log } \\
\text { Likelihooc }\end{array}$ & 476.9691 & & & & 292.3812 & & & \\
\hline Jarque Bera & 2310.875 & & Prob & 0 & 181557.9 & & Prob & 0 \\
\hline \multirow[t]{2}{*}{ Ljung-Box } & 0.019594 & & Prob & 0.888677 & 0.009483 & & Prob & 0.922426 \\
\hline & \multicolumn{4}{|c|}{$\begin{array}{l}\text { GARCH }(1,1) \text { estimation of transport and } \\
\text { communication }\end{array}$} & \multicolumn{4}{|c|}{$\begin{array}{l}\text { GARCH }(1,1) \text { estimation of banks and other financial } \\
\text { institutions }\end{array}$} \\
\hline Method & \multicolumn{4}{|c|}{ ML - BFGS with analytical gradient } & \multicolumn{4}{|c|}{ ML - BFGS with analytical gradient } \\
\hline $\begin{array}{l}\text { Included } \\
\text { observations }\end{array}$ & \multicolumn{4}{|c|}{197} & \multicolumn{4}{|c|}{197} \\
\hline \multirow[t]{2}{*}{$\begin{array}{l}\text { Convergence } \\
\text { achieved }\end{array}$} & \multicolumn{4}{|c|}{ after 20 iterations } & \multicolumn{4}{|c|}{ after 92 iterations } \\
\hline & Coefficient & Std. Error & $z$-Statistic & Prob. & Coefficient & Std. Error & $z$-Statistic & Prob. \\
\hline Omega & 0.010872 & 0.004924 & 2.208016 & 0.027243 & $5.944 \mathrm{E}-05$ & $5.38 \mathrm{E}-06$ & 11.05211 & 0 \\
\hline alpha_1 & 0.05 & 0.419846 & 0.119091 & 0.905203 & 0.4004756 & 0.04199 & 9.53738 & 0 \\
\hline beta_1 & 0.05 & 0.006433 & 7.771958 & 7.77E-15 & 0.9501401 & 0.171459 & 5.541492 & $3 \mathrm{E}-08$ \\
\hline $\begin{array}{l}\text { Log } \\
\text { Likelihooc }\end{array}$ & 200.8177 & & & & 542.05405 & & & \\
\hline Jarque Bera & 64087.74 & & Prob & 0 & 1839.1082 & & Prob & 0 \\
\hline \multirow[t]{2}{*}{ Ljung-Box } & 16.91545 & & Prob & 3.91E-05 & 65535 & & Prob & 65535 \\
\hline & \multicolumn{4}{|c|}{$\begin{array}{l}\text { GARCH }(1,1) \text { estimation of banks and investment } \\
\text { companies }\end{array}$} & \multicolumn{4}{|c|}{ GARCH $(1,1)$ estimation of modarabs } \\
\hline Method & \multicolumn{4}{|c|}{ ML - BFGS with analytical gradient } & \multicolumn{4}{|c|}{ ML - BFGS with analytical gradient } \\
\hline $\begin{array}{l}\text { Included } \\
\text { observations }\end{array}$ & \multicolumn{4}{|c|}{197} & \multicolumn{4}{|c|}{197} \\
\hline $\begin{array}{l}\text { Convergence } \\
\text { achieved }\end{array}$ & & after $62 \mathrm{it}$ & ations & & & after 33 & rations & \\
\hline & Coefficient & Std. Error & $z$-Statistic & Prob. & Coefficient & Std. Error & $z$-Statistic & Prob. \\
\hline Omega & 0.000139 & $3.9 \mathrm{E}-05$ & 3.557445 & 0.000374 & 0.004791 & 0.033623 & 0.142491 & 0.886693 \\
\hline alpha_1 & 0.490527 & 0.130154 & 3.768829 & 0.000164 & 0.041977 & 6.723337 & 0.006244 & 0.995018 \\
\hline beta_1 & 0.140946 & 0.038461 & 3.66462 & 0.000248 & 0.001494 & 0.013208 & 0.113077 & 0.90997 \\
\hline $\begin{array}{l}\text { Log } \\
\text { Likelihooc }\end{array}$ & 503.9013 & & & & 228.3536 & & & \\
\hline Jarque Bera & 1265.719 & & Prob & 0 & 202134.8 & & Prob & 0 \\
\hline Ljung-Box & 0.052522 & & Prob & 0.818732 & 0.008185 & & Prob & 0.927913 \\
\hline & GARCH & ) estimatio & of leasing co & panies & GAF & $\mathrm{H}(1,1)$ esti & ation of insu & nce \\
\hline Method & ML & FGS with a & lytical gradi & & ML & BFGS with & alytical grac & \\
\hline $\begin{array}{l}\text { Included } \\
\text { observations }\end{array}$ & & 19 & & & & & & \\
\hline $\begin{array}{l}\text { Convergence } \\
\text { achieved }\end{array}$ & & after $44 \mathrm{it}$ & ations & & & after 42 & rations & \\
\hline
\end{tabular}


End of Table 2

\begin{tabular}{|c|c|c|c|c|c|c|c|c|}
\hline & Coefficient & Std. Error & $z$-Statistic & Prob. & Coefficient & Std. Error & $z$-Statistic & Prob. \\
\hline Omega & 0.00015 & 0.000496 & 0.301817 & 0.762791 & 0.000946 & 4.07E-05 & 23.26315 & 0 \\
\hline alpha_1 & 0.054241 & 3.117997 & 0.017396 & 0.986121 & 0.006132 & 0.039833 & 0.153949 & 0.87764 \\
\hline beta_1 & 0.005465 & 0.035191 & 0.155297 & 0.876587 & 0.464921 & 0.154345 & 3.012225 & 0.002593 \\
\hline $\begin{array}{l}\text { Log } \\
\text { Likelihooc }\end{array}$ & 567.2291 & & & & 391.6546 & & & \\
\hline Jarque Bera & 3552.737 & & Prob & 0 & 57301.06 & & Prob & 0 \\
\hline \multirow[t]{2}{*}{ Ljung-Box } & 0.074254 & & Prob & 0.785241 & 0.01191 & & Prob & 0.913097 \\
\hline & \multicolumn{4}{|c|}{ GARCH $(1,1)$ estimation of miscellaneous } & \multicolumn{4}{|c|}{ GARCH $(1,1)$ estimation of jute } \\
\hline Method & \multicolumn{4}{|c|}{ ML - BFGS with analytical gradient } & \multicolumn{4}{|c|}{ ML - BFGS with analytical gradient } \\
\hline $\begin{array}{l}\text { Included } \\
\text { observations }\end{array}$ & \multicolumn{4}{|c|}{197} & \multicolumn{4}{|c|}{197} \\
\hline $\begin{array}{l}\text { Convergence } \\
\text { achieved }\end{array}$ & \multicolumn{4}{|c|}{ after 35 iterations } & \multicolumn{4}{|c|}{ after 82 iterations } \\
\hline
\end{tabular}

\begin{tabular}{|c|c|c|c|c|c|c|c|c|}
\hline & Coefficient & Std. Error & $z$-Statistic & Prob. & Coefficient & Std. Error & $z$-Statistic & Prob. \\
\hline Omega & 0.00398 & 0.110759 & 0.035934 & 0.971335 & 0.000399 & $8.57 \mathrm{E}-05$ & 4.662294 & $3.13 \mathrm{E}-06$ \\
\hline alpha_1 & 0.033047 & 26.90933 & 0.001228 & 0.99902 & 0.275655 & 0.155547 & 1.772167 & 0.076367 \\
\hline beta_1 & 0.000317 & 0.010799 & 0.029367 & 0.976572 & 0.446583 & 0.250674 & 1.781532 & 0.074826 \\
\hline $\begin{array}{l}\text { Log } \\
\text { Likelihooc }\end{array}$ & 251.134 & & & & 438.6181 & & & \\
\hline Jarque Bera & 190080.6 & & Prob. & 0 & 36043.81 & & Prob. & 0 \\
\hline \multirow[t]{2}{*}{ Ljung-Box } & 0.004049 & & Prob. & 0.94926 & 0.023525 & & Prob. & 0.878099 \\
\hline & \multicolumn{4}{|c|}{ GARCH $(1,1)$ estimation of food and allied } & \multicolumn{4}{|c|}{ GARCH $(1,1)$ estimation of glass and ceramics } \\
\hline Method & \multicolumn{4}{|c|}{ ML - BFGS with analytical gradient } & \multicolumn{4}{|c|}{ ML - BFGS with analytical gradient } \\
\hline $\begin{array}{l}\text { Included } \\
\text { observations }\end{array}$ & \multicolumn{4}{|c|}{197} & \multicolumn{4}{|c|}{197} \\
\hline \multirow[t]{2}{*}{$\begin{array}{l}\text { Convergence } \\
\text { achieved }\end{array}$} & \multicolumn{4}{|c|}{ after 36 iterations } & \multicolumn{4}{|c|}{ after 34 iterations } \\
\hline & Coefficient & Std. Error & $z$-Statistic & Prob. & Coefficient & Std. Error & $z$-Statistic & Prob. \\
\hline Omega & 0.003277 & 0.040787 & 0.080332 & 0.935973 & 0.005293 & 0.0433 & 0.122248 & 0.902703 \\
\hline alpha_1 & 0.040087 & 11.94931 & 0.003355 & 0.997323 & 0.040823 & 7.846122 & 0.005203 & 0.995849 \\
\hline beta_1 & 0.00028 & 0.01264 & 0.022123 & 0.98235 & 0.001228 & 0.014947 & 0.082188 & 0.934498 \\
\hline $\begin{array}{l}\text { Log } \\
\text { Likelihooc }\end{array}$ & 288.9329 & & & & 241.9424 & & & \\
\hline Jarque Bera & 258509.7 & & Prob. & 0 & 237973.2 & & Prob. & 0 \\
\hline \multirow[t]{2}{*}{ Ljung-Box } & 0.006319 & & Prob. & 0.93664 & 0.006829 & & Prob. & 0.934139 \\
\hline & \multicolumn{4}{|c|}{ GARCH $(1,1)$ estimation of vanaspati and allied } & \multicolumn{4}{|c|}{ GARCH $(1,1)$ estimation of others } \\
\hline Method & \multicolumn{4}{|c|}{ ML - BFGS with analytical gradient } & \multicolumn{4}{|c|}{ ML - BFGS with analytical gradient } \\
\hline $\begin{array}{l}\text { Included } \\
\text { observations }\end{array}$ & \multicolumn{4}{|c|}{197} & \multicolumn{4}{|c|}{197} \\
\hline \multirow[t]{2}{*}{$\begin{array}{l}\text { Convergence } \\
\text { achieved }\end{array}$} & \multicolumn{4}{|c|}{ after 35 iterations } & \multicolumn{4}{|c|}{ after 34 iterations } \\
\hline & Coefficient & Std. Error & $z$-Statistic & Prob. & Coefficient & Std. Error & $z$-Statistic & Prob. \\
\hline Omega & 0.001696 & 0.005994 & 0.282984 & 0.777189 & 0.005545 & 0.010817 & 0.512623 & 0.608215 \\
\hline alpha_1 & 0.053583 & 3.341321 & 0.016037 & 0.987205 & 0.038671 & 1.875249 & 0.020622 & 0.983547 \\
\hline beta_1 & 0.001698 & 0.017388 & 0.097675 & 0.92219 & 0.005176 & 0.019669 & 0.263166 & 0.792422 \\
\hline $\begin{array}{l}\text { Log } \\
\text { Likelihooc }\end{array}$ & 326.3105 & & & & 215.7244 & & & \\
\hline Jarque Bera & 36783.4 & & Prob. & 0 & 301694.8 & & Prob. & 0 \\
\hline Ljung-Box & 0.039675 & & Prob. & 0.842117 & 0.005378 & & Prob. & 0.941537 \\
\hline
\end{tabular}


There are 34 sectors in KSE. Out of these 34 sectors, 24 sectors were selected for the research. We took monthly observations for 17 years and we got the results for all the 24 sectors. However due to lack of significance in 21 sectors we were only able to work on the remaining 3 sectors for which there was significant evidence of ARCH and GARCH effects (Engle 2001). Table of significant and insignificant is provided in Table 3.

Table 3. Significant and insignificant ARCH \& GARCH effects

\begin{tabular}{lccc}
\hline \multicolumn{1}{c}{ Sectors } & $\begin{array}{c}\text { p-val } \\
\text { ARCH }(\alpha)\end{array}$ & $\begin{array}{c}\text { p-val } \\
\text { GARCH }(\beta)\end{array}$ & $\begin{array}{c}\text { Significiance } \\
\text { Level }\end{array}$ \\
\hline Banks and other Financial Institutions & 0 & $3.00 \mathrm{E}-08$ & Significant \\
\hline Banks \& Investment Co. & 0.000164 & 0.000248 & Significant \\
\hline Jute & 0.076367 & 0.074826 & Significant \\
\hline \hline Cotton and Other Textiles & 0 & 0.110994 & Insignificant \\
\hline Textile Spinning & 0.992362 & 0.885748 & Insignificant \\
\hline Textile Weaving & 0.980063 & 0.962012 & Insignificant \\
\hline Other Textiles & 0 & $2.37 \mathrm{E}-09$ & Insignificant \\
\hline Chemical \& Pharmaceutical & 0.993241 & 0.88576 & Insignificant \\
\hline Engineering & 0.978872 & 0.839497 & Insignificant \\
\hline Auto and Allied & 0.994648 & 0.911808 & Insignificant \\
\hline Cables and Electrical Goods & 0.994762 & 0.95534 & Insignificant \\
\hline Sugar and Allied & 0.881709 & 0.816746 & Insignificant \\
\hline Paper and Board & 0.998524 & 0.999263 & Insignificant \\
\hline Cement & 0.634748 & $3.69 \mathrm{E}-07$ & Insignificant \\
\hline Fuel and Energy & 0.997295 & 0.952515 & Insignificant \\
\hline Transport and Communication & 0.905203 & $7.77 \mathrm{E}-15$ & Insignificant \\
\hline Modarabas & 0.995018 & 0.90997 & Insignificant \\
\hline Leasing Companies & 0.986121 & 0.876587 & Insignificant \\
\hline Insurance & 0.87765 & 0.002593 & Insignificant \\
\hline Miscellaneous & 0.99902 & 0.976572 & Insignificant \\
\hline Food and Allied & 0.997323 & 0.98235 & Insignificant \\
\hline Glass and Ceramics & 0.995849 & 0.934498 & Insignificant \\
\hline Vanaspati and Allied & 0.987205 & 0.92219 & Insignificant \\
\hline Others & 0.983547 & 0.792422 & Insignificant \\
\hline & & &
\end{tabular}

\section{Conclusions}

Market movements are generally considered to be unpredictable by many investors and they try to make up for that by buying and holding securities in the market with the hope of making the average market return over long periods of time. However there is one school of thought that says that market behavior is predictable and that it is possible for investors to make excess returns over the market. One such concept is the mean reversion process which simply states that market prices/returns are mean reverting and that if an investor is 
able to determine high and low levels of the market he may be able to derive a mean value around which returns move.

This study looks at the volatilities in returns in the sectors of the KSE (Karachi Stock Exchange) and attempts to determine the pace of mean reversion in the given sectors. We have used the GARCH $(1,1)$ model in order to determine if both the GARCH and ARCH effects are significant in each of the individual sectors so that we may be able to determine if mean reversion exists in the given sectors based on given data. After determining whether mean reversion exists or not, our model shows whether the mean reversion process is fast or slow in the given sectors.

The two sectors in which the GARCH and ARCH effects were significant are Jute and, banks and investment companies. For these given sectors the LRAV for Jute is highest (3.79\%) along with the greatest trailing variance (0.446). The LRAV for Banks and Investment companies is $1.94 \%$ and its trailing variance is 0.140 , which is lower than the trailing variance for Jute. The sums of GARCH coefficients are 0.7226 for Jute and 0.631 for Banks and Investment Companies. This means that the pace of mean reversion in Banks and Investment Companies is greater as compared to the speed of mean reversion in Jute.

\section{References}

Andreou, E.; Werker, B. J. M. 2015. Residual-based rank specification tests for AR-GARCH type models, Journal of Econometrics 185(2): 305-331. http://dx.doi.org/10.1016/j.jeconom.2014.11.001

Bailey, G.; Gilbert, E. 2007. The impact of liquidity on mean reversion of share returns of the JSE, Investment Analysts Journal 36(66): 19-29. http://dx.doi.org/10.1080/10293523.2007.11082490

Balvers, R.; Wu, Y.; Gilliland, E. 2000. Mean reversion across national stock markets and parametric contrarian investment strategies, The Journal of Finance 55(2): 745-772. http://dx.doi.org/10.1111/0022-1082.00225

Bentes, S. R. 2015. A comparative analysis of the predictive power of implied volatility indices and GARCH forecasted volatility, Physica a-Statistical Mechanics and its Applications 424: 105-112. http://dx.doi.org/10.1016/j.physa.2015.01.020

Black, F. 1976. Study of stock price volatility changes, Proceedings of the 1976 Meetings of the Business and Economic Statistics Section, American Statistical Association, Washington, D.C., 177-181.

Bollerslev, T. 1986. Generalized autoregressive conditional heteroskedasticity, Journal of Econometrics 31(3): 307-327. http://dx.doi.org/10.1016/0304-4076(86)90063-1

Boussaidi, R.; Kouki, M. 2015. Stock price mean reversion to fundamentals and long-run return predictability in the Tunisian stock market, International Journal of Business and Management 10(8): 183-197. http://dx.doi.org/10.5539/ijbm.v10n8p183

Campbell, J. Y.; Shiller, R. 1988. Stock prices, earnings, and expected dividends, Journal of Finance 43(3): 661-676. http://dx.doi.org/10.1111/j.1540-6261.1988.tb04598.x

Campbell, J. Y.; Shiller, R. 2001. Valuation ratios and the long-run stock market outlook: an anupdate, NBER working paper 8221. http://dx.doi.org/10.3386/w8221

Campbell, J. Y.; Viceira, L. M. 2005. The term structure of the risk-return trade-off, Financial Analysts Journal 61(1): 34-44. http://dx.doi.org/10.3386/w11119

Cecchetti, S. G.; Lam, P. S.; Mark, N. C. 1990. Mean reversion in equilibrium asset prices, American Economic Review 80(3): 398-418. http://dx.doi.org/10.1111/j.1540-6261.1995.tb05178.x 
Cubbin, E.; Eidne, M.; Firer, C.; Gilbert, E. 2006. Mean reversion on the JSE securities exchange, Investment Analysts Journal 35(63): 39-47. http://dx.doi.org/10.1080/10293523.2006.11082477

Cutler, D. M.; Poterba, J. M.; Summers, L. H. 1991. Speculative dynamics, Review of Economic Studies 58(3): 529-546. http://dx.doi.org/10.2307/2298010

De Bondt, W. F. M.; Thaler, R. 1985. Does the stock market overreact?, Journal of Finance 40(3): $793-$ 805. http://dx.doi.org/10.1111/j.1540-6261.1985.tb05004.x

De Bondt, W. F. M.; Thaler, R. 1987. Further evidence on investor overreactionand stock market seasonality, Journal of Finance 42(3): 557-581. http://dx.doi.org/10.1111/j.1540-6261.1987.tb04569.x

Dennis, P. J.; Strickland, D. 2002. Who blinks in volatile markets, individuals or institutions?, Journal of Finance October 57(5): 1923-1949. http://dx.doi.org/10.1111/0022-1082.00484

Easton, D. P.; Wild, J. J.; Halsey, R. F.; McAnally, M. L. 2013. Financial accounting for MBAs. Cambridge Business Publishers.

Engle, R. F. 2001. GARCH 101: The use of ARCH/GARCH models in applied econometrics, Journal of Economic Perspectives 15(4): 157-168. http://dx.doi.org/10.1257/jep.15.4.157

Engle, R. F.; Ng, V. K. 1993. Measuring and testing the impact of news on volatility, Journal of Finance 48(5): 1749-1778. http://dx.doi.org/10.1111/j.1540-6261.1993.tb05127.x

Fama, E. F. 1960. The behavior of stock market prices, Journal of Business 38(1): 34-105. http://dx.doi.org/10.1086/294743

Fama, E. F.; French, K. R. 1988a. Dividend yields and expected stock returns, Journal of Financial Economics 22(1): 3-25. http://dx.doi.org/10.1016/0304-405X(88)90020-7

Fama, E. F.; French, K. R. 1988b. Permanent and temporary components of stock prices, The Journal of Political Economy 96(2): 246-273. http://dx.doi.org/10.1086/261535

Ghysels, E.; Harvey, A. C.; Renault, E. 1996. Stochastic volatility, in C. R. Rao, G. S. Maddala (Eds.). Statistical methods in finance. Amsterdam, North-Holland, 119-191. http://dx.doi.org/10.1016/S0169-7161(96)14007-4

Girdzijauskas, S.; Čepinskis, J.; Jurkonyte, E. 2008. Transformations in insurance market: modern accouting method of insurance tariffs, Transformations in Business and Economics 7(2(14)): 143-153.

Gordon, M. J. 1959. Dividends, earnings and stock prices, Review of Economics and Statistics 41(2): 99-105. The MIT Press. http://dx.doi.org/10.2307/1927792

Gordon, M. J. 1962. The investment, financing, and valuation of the corporation. Homewood, IL: R. D. Irwin.

Han, H. 2015. Asymptotic properties of GARCH-X processes, Journal of Financial Econometrics 13(1): 188-221. http://dx.doi.org/10.1093/jjfinec/nbt023

Hansen, L. P.; Hodrick, R. J. 1980. Forward exchange rates as optimal predictors of future spot rates: an econometric analysis, The Journal of Political Economy 88(5): 829-853. http://dx.doi.org/10.1086/260910

Hillebrand, E. 2003. A mean-reversion theory of stock-market crashes, Journal of Finance 41: 591-601.

Iqbal, H.; Riaz, T. 2015. The empirical relationship between stocks returns, trading volume and volatility: evidence from stock market of United Kingdom, Research Journal of Finance and Accounting 6(13): 180-192.

Jegadeesh, N. 1991. Seasonality in stock price mean reversion: evidence from the U.S. and the U.K., Journal of Finance 46(4): 1427-1444. http://dx.doi.org/10.1111/j.1540-6261.1991.tb04624.x

Kasa, K. 1992. Common stochastic trends in international stock markets, Journal of Monetary Economics 29(1): 95-124. http://dx.doi.org/10.1016/0304-3932(92)90025-W

Kim, M. J.; Nelson, C.; Startz, R. 1991. Mean reversion in stock prices? A reappraisal of the empirical evidence, Review of Economic Studies 58(195): 515-528. http://dx.doi.org/10.3386/w2795 
Kinoshita, R. 2015. Asset allocation under higher moments with the GARCH filtre, Empirical Economics 49(1): 235-254. http://dx.doi.org/10.1007/s00181-014-0871-1

Kitatia, E.; Zablonb, E.; Maithyac, H. 2015. Effect of macro-economic variables on stock market prices for the companies quoted on the nairobi securities exchange in Kenya, International Journal of Sciences: Basic and Applied Research 21(2): 235-263.

Kononovicius, A.; Ruseckas, J. 2015. Nonlinear GARCH model and 1/f noise, Physica A - Statistical Mechanics and its Applications 427: 74-81. http://dx.doi.org/10.1016/j.physa.2015.02.040

Kristjanpoller, W.; Minutolo, M. C. 2015. Gold price volatility: a forecasting approach using the Artificial Neural Network-GARCH model, Expert Systems with Applications 42(20): 7245-7251. http://dx.doi.org/10.1016/j.eswa.2015.04.058

Liu, X. C.; Luger, R. 2015. Unfolded GARCH models, Journal of Economic Dynamics \& Control 58: 186-217. http://dx.doi.org/10.1016/j.jedc.2015.06.007

Lo, A. W.; MacKinlay, C. 1988. Stock market prices do not follow random walks: evidence from a simple specification test, Review of Financial Studies 1(1): 41-66. http://dx.doi.org/10.1093/rfs/1.1.41

Mackevicius, R.; Girdzijauskas, S.; Streimikiene, D.; Barakauskaite-Jakubauskiene, N. 2012. Logistic aspects of Japan economic development, Transformation in Business and Economics 10(1): 58-79.

Malliaropulos, D.; Priestley, R. 1999. Mean reversion in Southeast Asian stock markes, Journal of Empirical Finance 6(4): 355-384. http://dx.doi.org/10.1016/S0927-5398(99)00010-9

Marin, J. M.; Rodriguez-Bernal, M. T.; Romero, E. 2015. Data cloning estimation of GARCH and COGARCH models, Journal of Statistical Computation and Simulation 85(9): 1818-1831. http://dx.doi.org/10.1080/00949655.2014.903948

Nam, K.; Pyun, C. S.; Kim, S. W. 2003. Is asymmetric mean-reverting pattern in stock returns systematic? Evidence from Pacific-basin markets in the short-horizon, Journal of International Financial Markets Institutions and Money 13(5): 481-502. http://dx.doi.org/10.1016/S1042-4431(03)00019-2

Orabi, M. M. A.; Alqurran, T. A.-A. 2015. Effect of volatility changes on emerging stock markets: the case of Jordan, Journal of Management Research 7(4): 132-143. http://dx.doi.org/10.5296/jmr.v7i4.7463

Paolella, M. S. 2015. Multivariate asset return prediction with mixture models, European Journal of Finance 21(13-14): 1214-1252. http://dx.doi.org/10.1080/1351847X.2012.760167

Pastor, L.; Stambaugh, R. F. 2012. Are stocks really less volatile in the long run?, Journal of Financial Economics 67(2): 431-478. http://dx.doi.org/10.1111/j.1540-6261.2012.01722.x

Pavlenko, A. 2008. A mean reversion in stock market prices: evidence from Ukraine: EERC Master thesis. National University "Kyiv-Mohyla Academy".

Posedel, P. 2005. Properties and Estimation of GARCH(1,1) Model, Metodološki Zvezki 2(2): 243-257.

Poterba, J.; Summers, L. 1988. Mean-reversion in stock prices: evidence and implications, Journal of Financial Economics 22: 27-59. http://dx.doi.org/10.3386/w2343

Richardson, M.; Smith, T. 1991. Tests of financial models in the presence of overlapping observations, Review of Financial Studies 4(2): 227-254. http://dx.doi.org/10.1093/rfs/4.2.227

Shephard, N. 1996. Statistical aspects of ARCH and stochastic volatility, in D. R. Cox, D. V. Hinkley, O. E. Barndorff-Nielson (Eds.). Time series models in econometrics, finance and other fields. London: Chapman \& Hall, 1-67. http://dx.doi.org/10.1007/978-1-4899-2879-5_1

Spierdijk, L.; Bikker, J.; Van Den Hoek, P. 2010. Mean reversion in international stock markets: an empirical analysis of the 20th century, De Nederlandsche Bank Working Paper 247 [online], [cited 20 June 2015]. Availaible from Internet: http://www.dnb.nl/en/binaries/Working\%20paper\%202472010_tcm47-232350.pdf

Summers, L. H. 1996. Does the stock market rationally reflect fundamental values?, Journal of Finance 41(3): 591-601. http://dx.doi.org/10.2307/2328487 
Teresiene, D.; Aarma, A.; Dubauskas, G. 2008 Relationship between stock market and macroeconomic violatility, Transformations in Business and Economics 7(22): 102-114.

Vlaar, P. 2005. Defined benefit pension plans and regulation, De Nederlandsche Bank Working Paper 63 [online], [cited 20 June 2015]. Available from Internet: http://www.dnb.nl/en/binaries/Working\%20 Paper\%2063_tcm47-146720.pdf

Wang, C. Y.; Guo, Y. Y.; Ye, Q. 2015. An anatomy of Chinese stock and futures markets' dynamic features, Applied Economics Letters 22(16): 1329-1334.

http://dx.doi.org/10.1080/13504851.2015.1029111

Zhu, F. K.; Shi, L.; Liu, S. Z. 2015. Influence diagnostics in log-linear integer-valued GARCH models, Asta-Advances in Statistical Analysis 99(3): 311-335. http://dx.doi.org/10.1007/s10182-014-0242-4

Jolita VVEINHARDT is a Chief Researcher at the Institute of Sports Science and Innovations of Lithuanian Sports University and Professor at the Faculty of Sport Education of Lithuanian Sports University. Her research activity is focused on mobbing in employee relations, organisational climate, nepotism as a management anomaly, values congruence, human resource management, corporate social responsibility, the knowledge-based economy. Her publications have appeared in the Journal of Business Economics and Management, Transformations in Business and Economics, Engineering economics and Problems and Perspectives in Management among others.

Dalia STREIMIKIENE is a Chief Researcher at the Institute of Sports Science and Innovations of Lithuanian Sports University. Her research activity is focused on macroeconomic environmnet of business, macroeconomic policies and measures, sustainable development, climate chnage mitigation issues and human resource managament issues. She has experience in various projects and research studines dealing with sustainability assessment.

Ahmed Raheem RIZWAN is a Professor at the Institute of Business Administration \& Commerce at Indus University (Pakistan); He obtained his PhD from Hamdard University, and MS (Economics) from SZABIST University, Karachi. He is also an independent consultant for the Pharmaceutical Industry for last several years. During his thorough research career of more than 12 years, he mainly focused on marketing strategy, Organizational performance, behavior of Stocks, money market portfolios and Liquidity market problems by using Time Series analysis models, Multivariate Regression, CFA \& EFA models. Besides, he also made a significant research in current issues related to Sales \& Marketing of local and global Pharmaceutical Industry; he used quantitative \& qualitative models for this purpose.

Ahmad NAWAZ is Visiting Professor at Department of Business Administration at Iqra University (Pakistan); He obtained his MBA \& M.Phil. (Economics) from SZABIST University, Karachi. He is also an independent researcher and Editor of a Journal for last 15 years. During his broad research career of more than 15 years, he mainly focused on macro \& microeconomics related issues of Pakistani economy, his research expertise area are macroeconomic indicators, study of stock prices and its behavior, comparison of financial security markets by using Time Series analysis models, Multivariate Regression models, and other Econometrics models. Besides, he also made a significant contribution of research for private sector employees' and Organizational related issues; he used quantitative models for these studies.

Anique REHMAN is a visiting Professor at department of Business Administration at Greenwich University (Karachi), He obtained MBA \& M.Phil. (Finance \& Economics) from Greenwich University, Karachi. He is also a Finance Manager in a leading corporate group. During his research career of more than 7 years he mainly focused macro \& microeconomics related issues of Pakistani economy. His areas of expertise are fiscal policy, budgetary deficit and money markets by using Time Series models, multivariate models and other Econometric models. 